\title{
Thumb Hypoplasia
}

National Cancer Institute

\section{Source}

National Cancer Institute. Thumb Hypoplasia. NCI Thesaurus. Code C98897.

A cong enital abnormality characterized by hypoplasia or absence of the thumb. It may be associated with other congenital abnormalities. 